\title{
Putative Martian Microbes Formed Plentiful Ooids on Mars
}

Lin L*

Alumnus of National Taiwan University, Taiwan

"Corresponding author: Lin L, Alumnus of National Taiwan University, Taiwan, E-mail: wretchfossil@gmail.com

Received date: Feb 29, 2016; Accepted date: March 29, 2016; Published date: April 08, 2016

Copyright: @ 2016 Lin L. This is an open-access article distributed under the terms of the Creative Commons Attribution License, which permits unrestricted use, distribution, and reproduction in any medium, provided the original author and source are credited.

\begin{abstract}
NASA's Mars Rover Curiosity discovered plentiful indigenous spherical ooids at High Dune and Namib Dune in Bagnold dune field, Gale Crater, Mars. Closely resembling ooids of Earth, the Martian ooids are spherical in shape, similar in size, mostly about $0.5 \mathrm{~mm}$ in diameter. Colors of the Martian ooids are various, including white, yellow translucent, green, grey, and yellow. The Martian ooids should have been formed by microbes, because ooids of Earth have recently been found to be formed by microbes and microbial borings are found in ooids of Earth and Mars. The Martian ooids are unlikely to have been formed by non-biological mechanisms, because there was no highly agitated water at the discovery sites.
\end{abstract}

Keywords: Martian microbes; Martian ooids; Life on Mars; Past life Introduction on Mars

NASA's Mars Rover Curiosity visited Bagnold dune field in Gale Crater, Mars, to study sands there from December 2015 to February 2016 (from Sol 1182 to Sol 1260) (Figure 1).

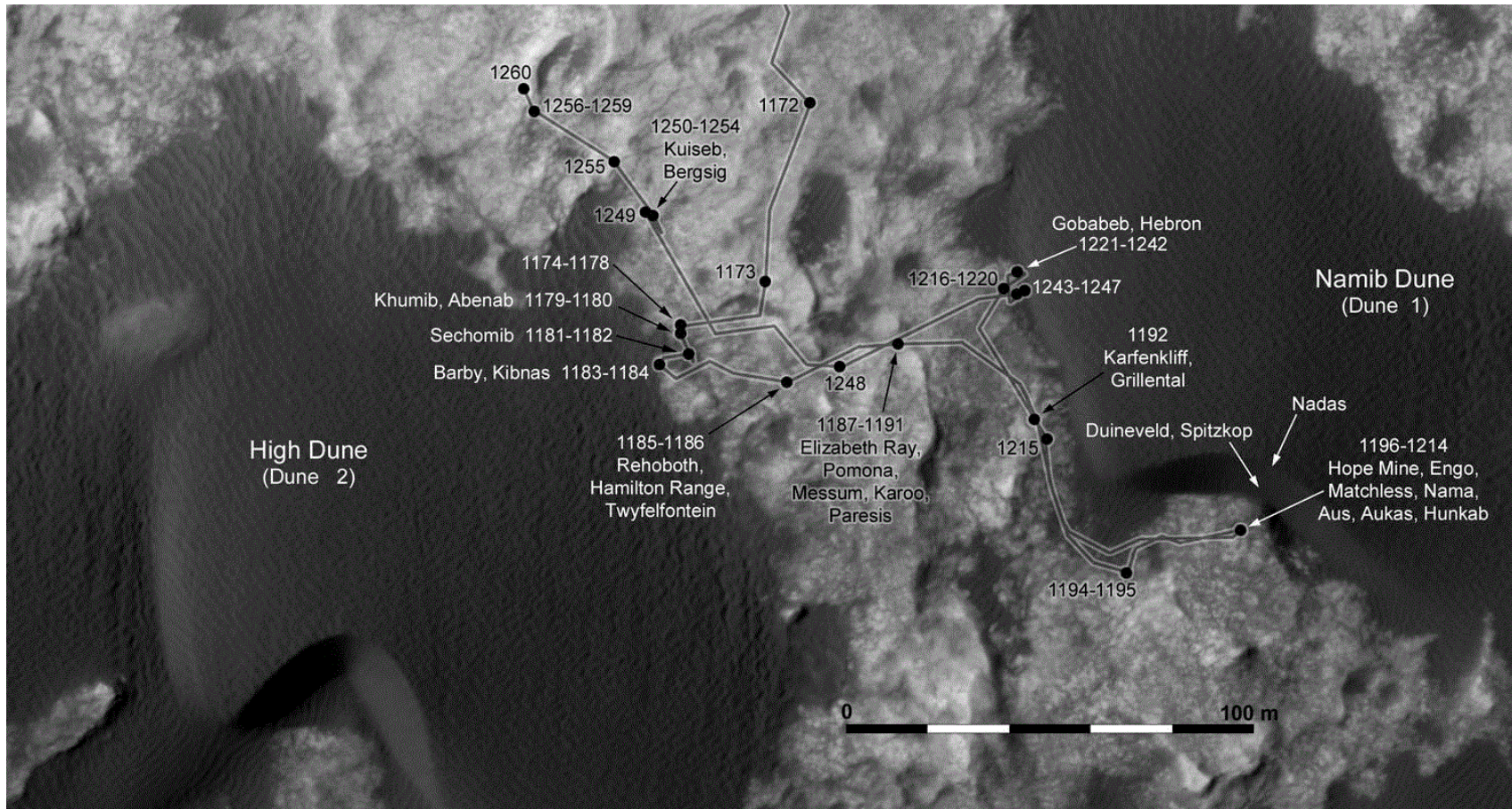

Figure 1: Route map of Mars Rover Curiosity from Sol 1172 to Sol 1260.

(Image Credit: NASA; Image Source: https://www.facebook.com/ marscuriosityimages/photos/a.

$584691531546000.149854 .584605114887975 / 1274505609231252 / ?$

type $=3 \&$ theater)
During its visit there, Curiosity Rover did a lot of science on Martian sands there, including the morphology, mineralogy, and chemistry of the sands. This article focuses on the rover's discovery of putative ooid sand based on the morphology of Martian sands there. Curiosity Rover used its Mars Hand Lens Imager (MAHLI) to acquire a lot of microscopic images of the sands there. Many of the 
microscopic images show ooids, some of which are marked in the following figures in the result section below.

\section{Results}

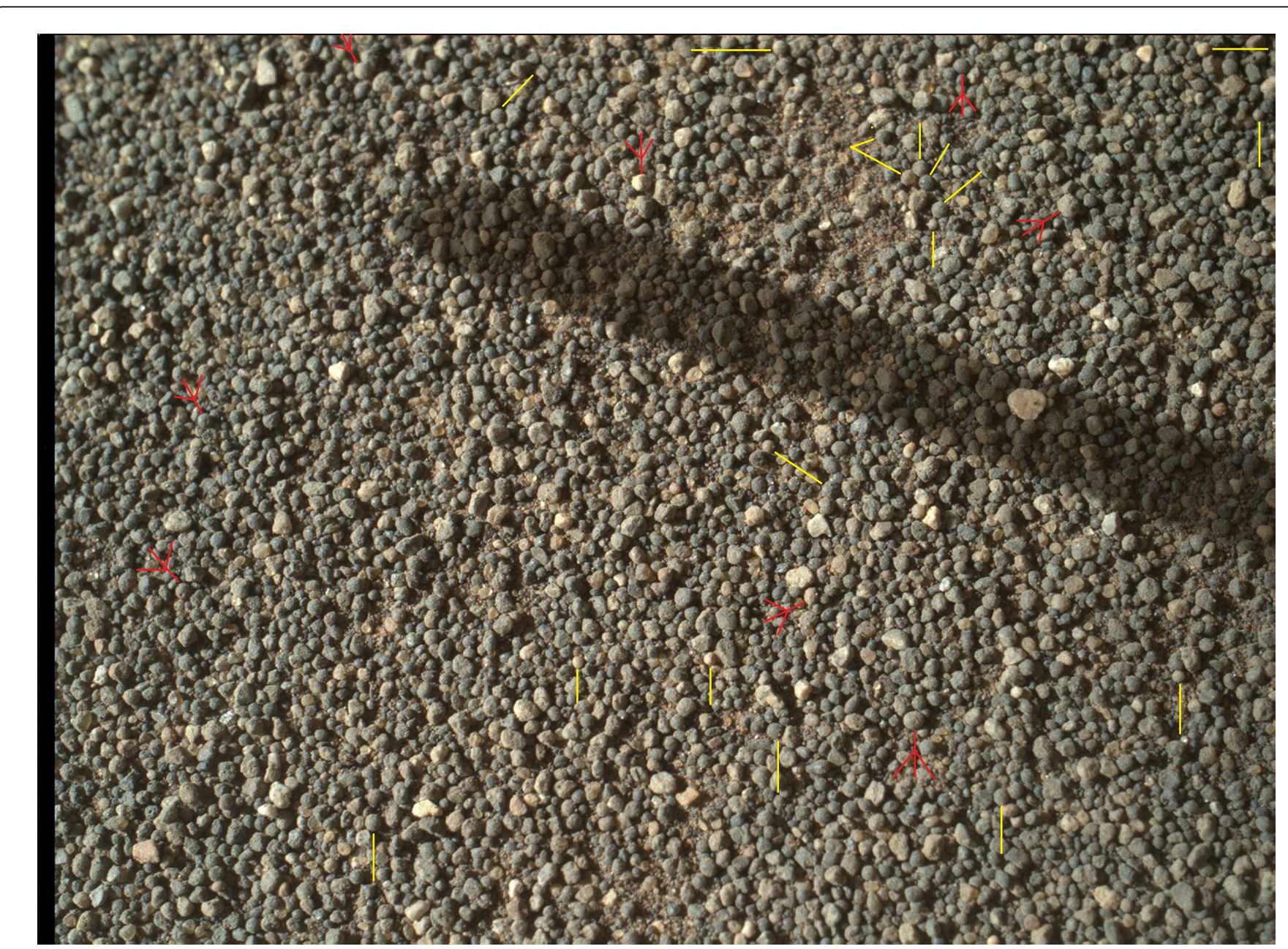

Figure 2: Martian ooids at High Dune.

The above microscopic image was acquired by NASA's Mars rover Curiosity on Dec 3, 2015 (Sol 1182) near High Dune, Gale Crater, Mars. Eight red arrows and 17 yellow lines mark ooids. They are all smaller than $1 \mathrm{~mm}$ in diameter. Image width: $\sim 3.3 \mathrm{~cm}$. (Note: Figures $2-5$ range from $\sim 2.8 \mathrm{~cm}$ to $\sim 3.8 \mathrm{~cm}$ in image widths) Image Credit: NASA/JPL-Caltech/MSSS; Image Source: http://mars.nasa.gov/msl/ multimedia/raw/?rawid=1182MH0003650010402637C00_DXXX\&s=1182
For comparison with ooids of Earth that resemble Martian ooids, see figures and photos in http://wretchfossil.blogspot.tw/2016/01/earthlyooids-for-comparison.html 


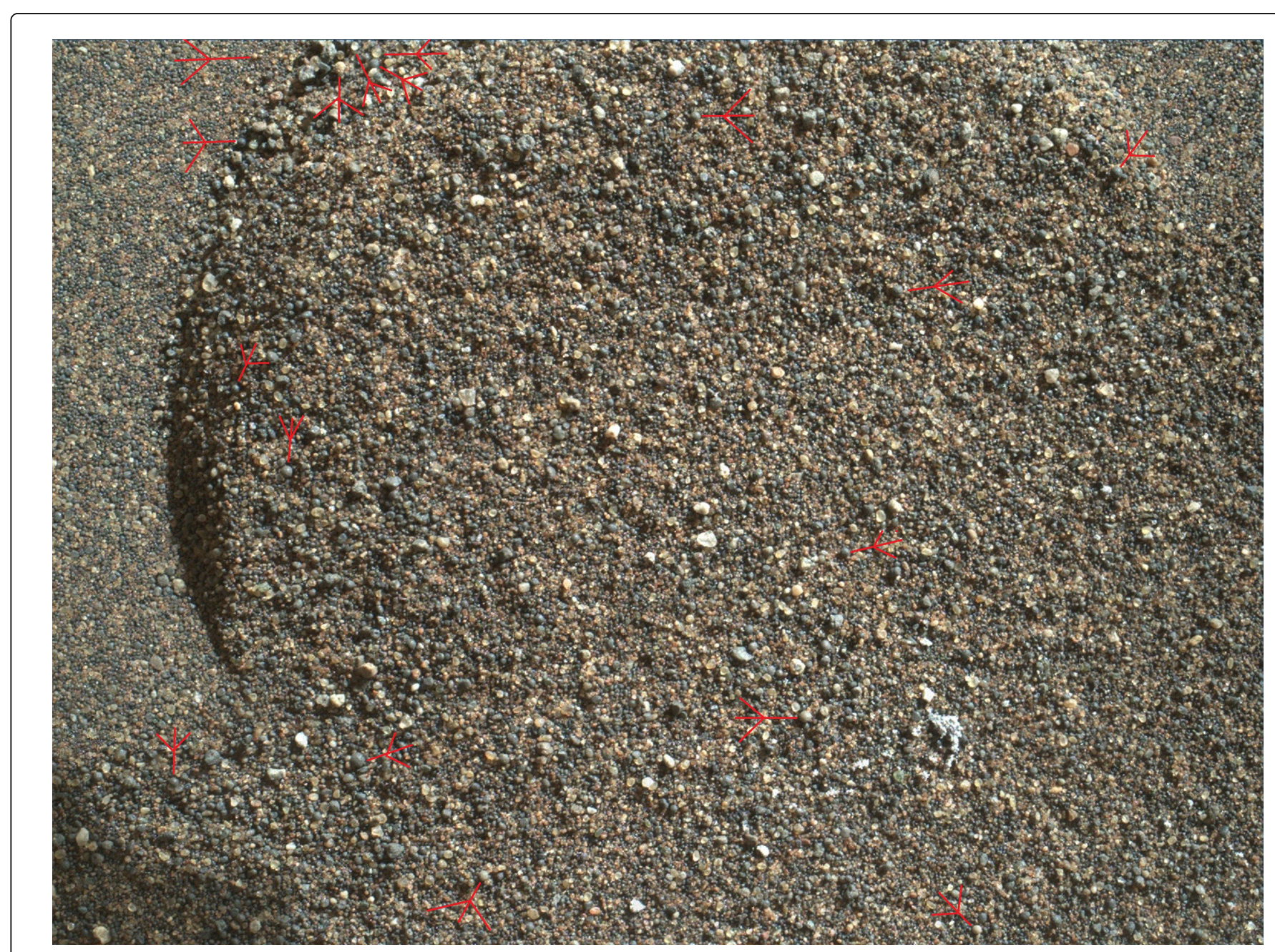

Figure 3: Well-preserved ooids at Namib Dune.

NASA's Mars Rover Curiosity acquired the above microscopic image on Jan 19, 2016 (Sol 1228) at Namib Dune in Bagnold dune field, Gale Crater, Mars. Seventeen red arrows point to well-preserved ooids. They are all smaller than $1 \mathrm{~mm}$ across. Two translucent ooids at top left seem to be made of calcite. Image width: $\sim 3.8 \mathrm{~cm}$. Image Credit: NASA/JPL-Caltech/MSSS; Image Source: http:// mars.nasa.gov/msl/multimedia/raw/?

rawid=1228MH0001630000403298R00_DXXX\&s=1228 


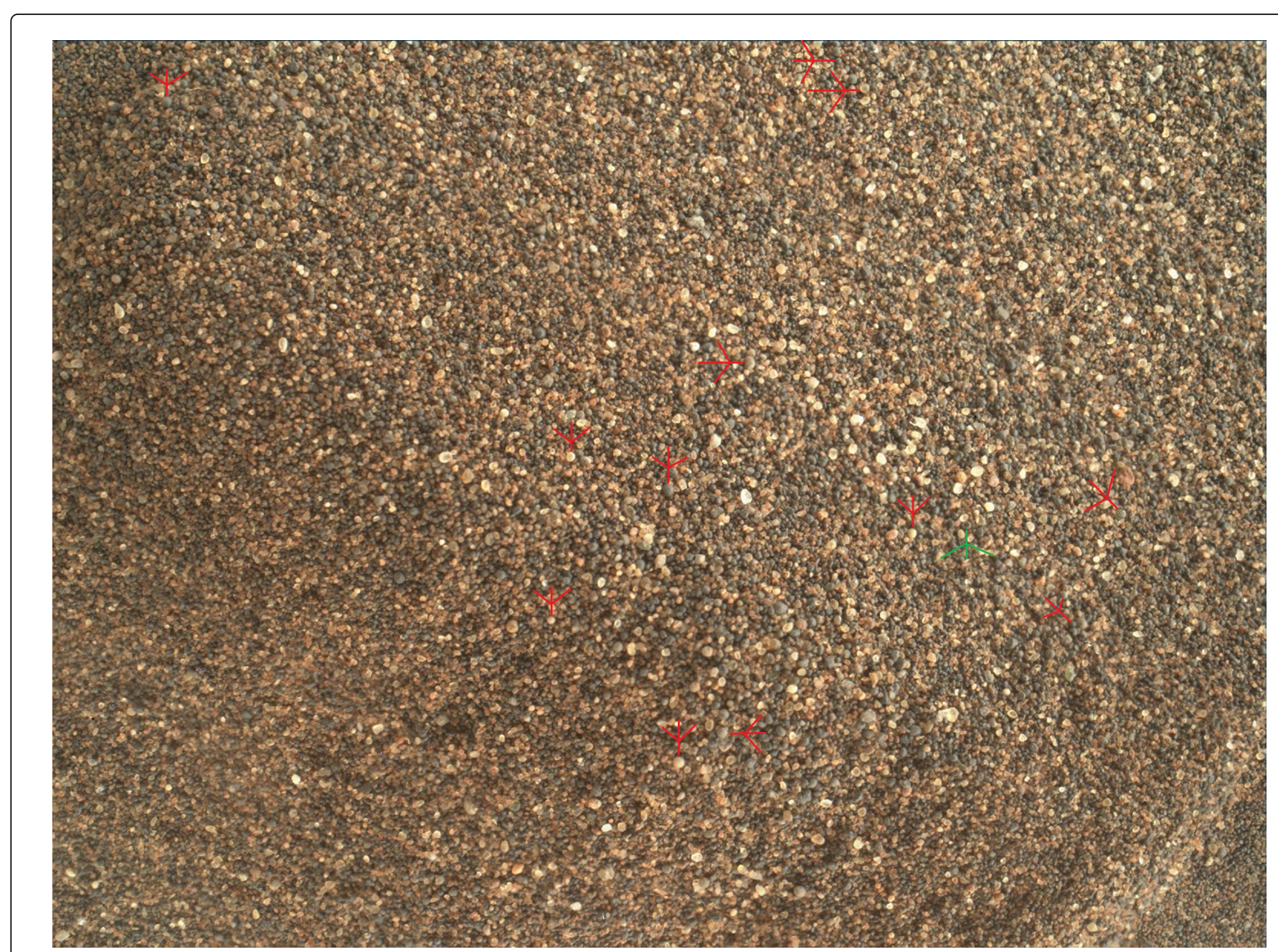

Figure 4: Well-preserved ooids in sieved sample.

NASA's Mars Rover Curiosity acquired the above microscopic image on Jan 19, 2016 (Sol 1228) at Namib Dune in Bagnold dune field, Gale Crater, Mars. Twelve red arrows point to well-preserved ooids. These ooids are smaller than $1 \mathrm{~mm}$ in diameter, as the imaged area is actually $\sim 3.3 \mathrm{~cm}$ wide. The rover dumped the scooped and sieved particles onto the ground after analyzing similar particles for their chemistry and mineralogy in its laboratory instruments. Image Credit: NASA/ JPL-Caltech/MSSS; Image Source: http://mars.nasa.gov/msl/multimedia/ raw/?rawid=1228MH0001700000403450R00_DXXX\&s=1228 


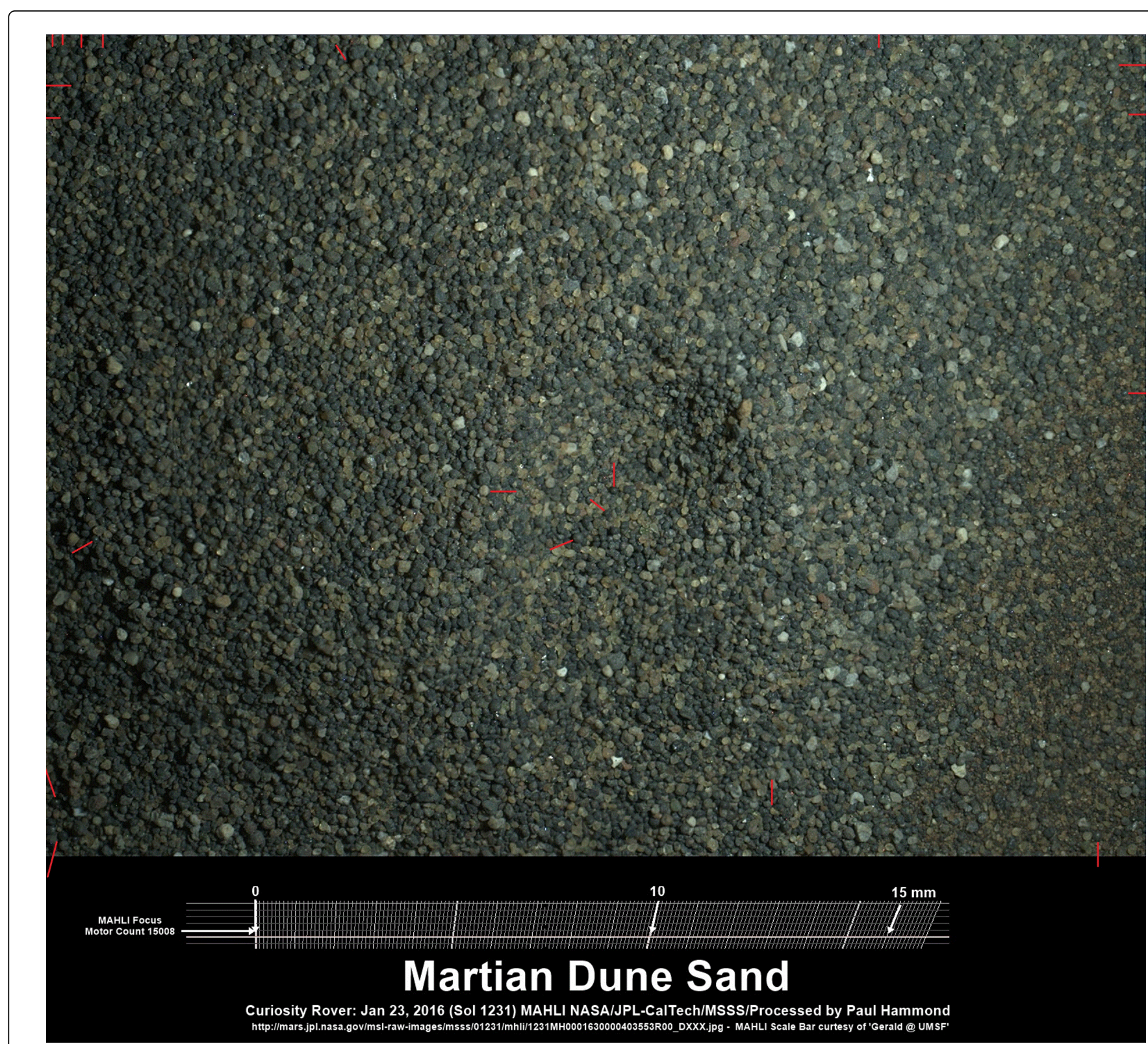

Figure 5: Most particles in this photo are ooids.

NASA's Mars Rover Curiosity acquired the above image with Mars Hand Lens Imager (MAHLI) on Jan 23, 2016 (Sol 1231) at Namib Dune in Bagnold dune field, Gale Crater, Mars. Most of the particles in this image are eroded ooids. Red lines mark some of the ooids. They are all smaller than $1 \mathrm{~mm}$ across. Image width: $\sim 2.8 \mathrm{~cm}$. Image Credit:
NASA/JPL-Caltech/MSSS; Image Source: www.flickr.com/photos/ 105796482@N04/24483811912/

NASA's Image: http://mars.jpl.nasa.gov/msl/multimedia/images/? ImageID $=7659$ 


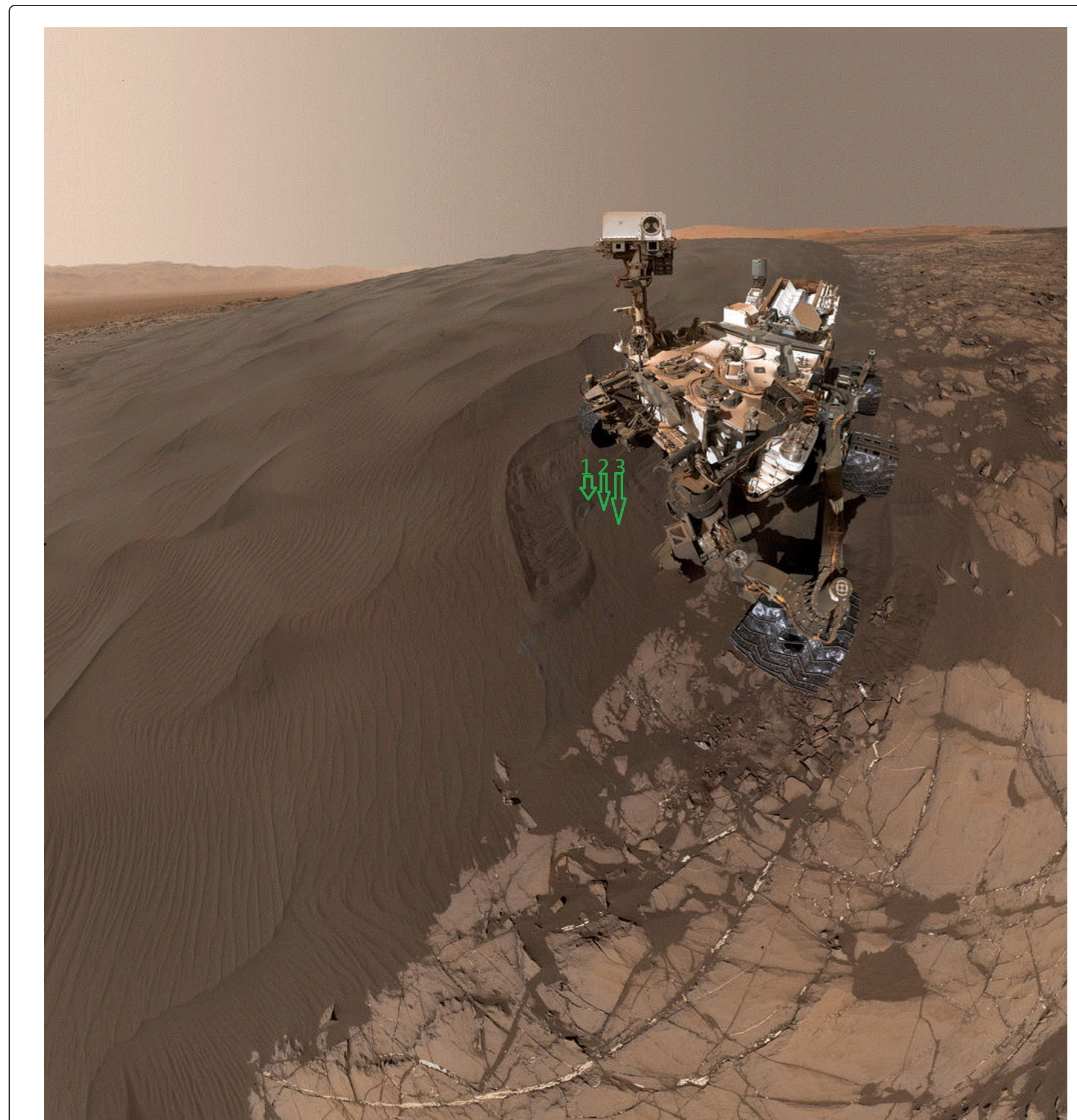

Figure 6: Geological context of Ooids at Namib Dune.

Three green arrows point to three spots where Mars Rover Curiosity scooped samples for chemical and mineralogical analyses with onboard instruments SAM and CheMin (Figure 6). After analyses, some samples were dumped onto ground and imaged with Mars Hand
Lens Imager. The material imaged in Figures 3-5 are from arrow 2 (Figure 3) and arrow 1 (Figures 4 and 5). Image Credit: NASA/JPLCaltech/MSSS; NASA's full-sized image with description: http:// mars.jpl.nasa.gov/msl/multimedia/images/?ImageID $=7658$ 


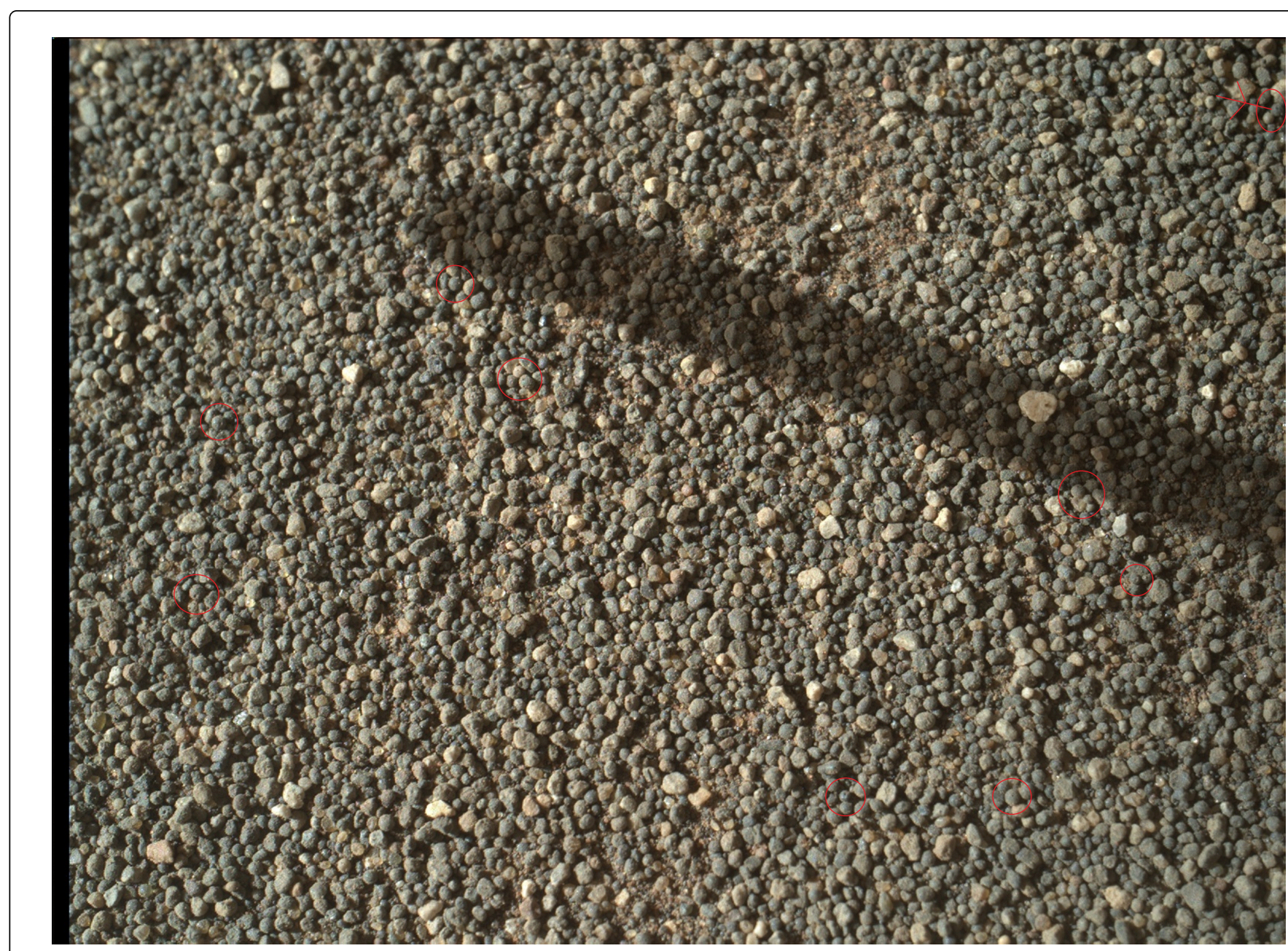

Figure 7: Microbes bored holes in these ooids.

Microbes of Earth often bore holes in ooids [1]. Microbes on Mars did the same thing in this photo (Figure 7), which is the same as Figure 2 above. In the red circles are Martian ooids with holes bored by Martian microbes. Image width: $\sim 3.3 \mathrm{~cm}$. Image Credit: NASA/JPLCaltech/MSSS; Image Source: http://mars.nasa.gov/msl/multimedia/raw/? rawid=1182MH0003650010402637C00_DXXX\&s=1182

Note 1: "The ooids have the same pattern of microboring alteration across the region. The surface and outer cortex of the ooids are punctuated with unfilled microborings, whereas the inner cortex contains two morphologies of aragonite cement filling the microborings" [1].

Note 2: "Examination of such micritic ooids by scanning electron microscopy often shows evidence of microbial borings later filled by fine cement." (quoted from Wikipedia article on ooids)

Note 3: Example of Earthly microbes boring holes in ooids can be seen at the center of the following photo: https://en.wikipedia.org/wiki/ Ooid\#/media/File:OoidSurface01.jpg 


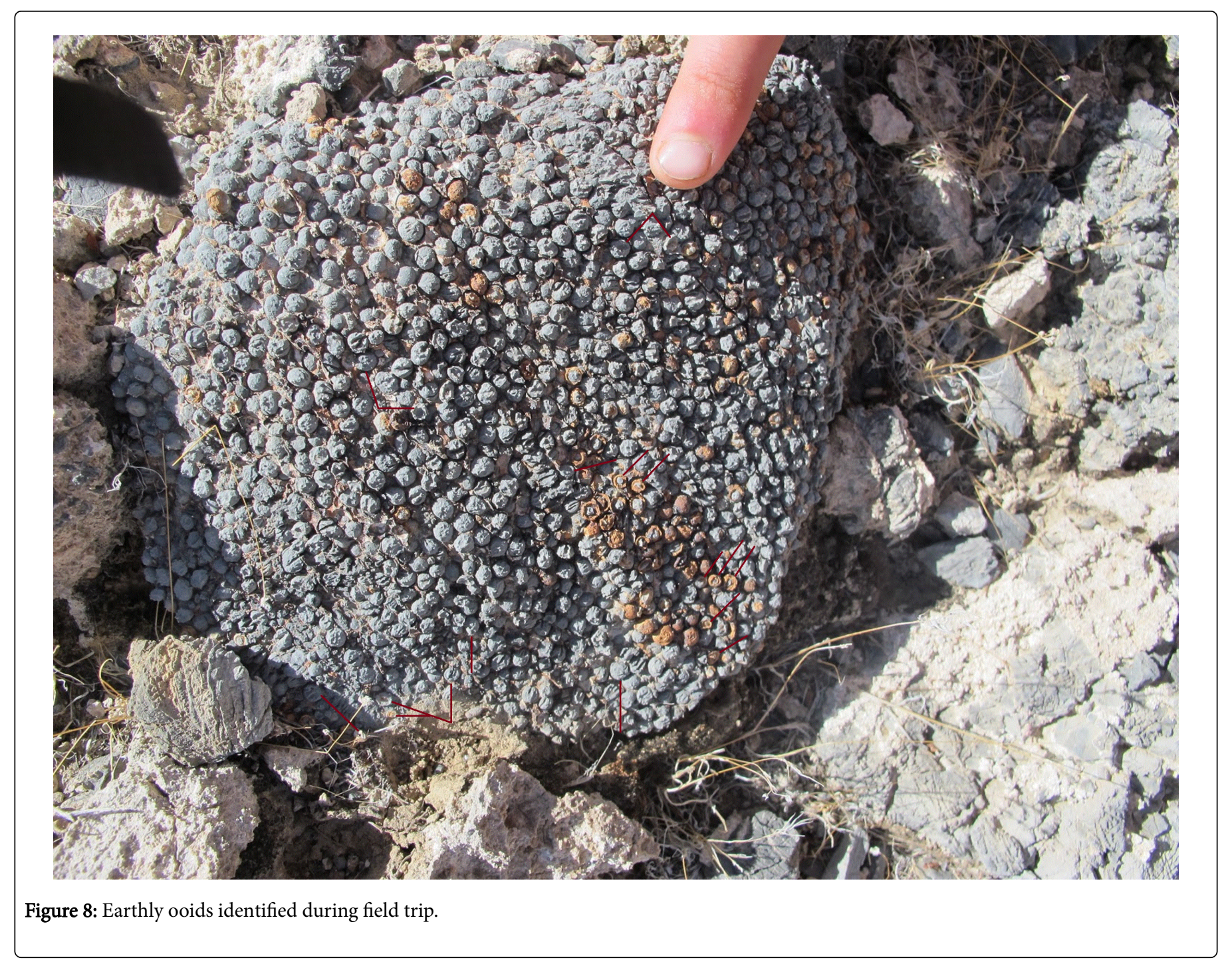

Original description: "Mega ooids! Dave's finger for scale." The hemispheres. Image Source: the last fifth photo in http:// above photo shows ooids in China Ranch, California, USA (Figure 8). daveandiztakeonthewest.blogspot.tw/2012/11/china-ranch-andRed lines in the photo mark ooids that have been eroded into stretchoween.html 

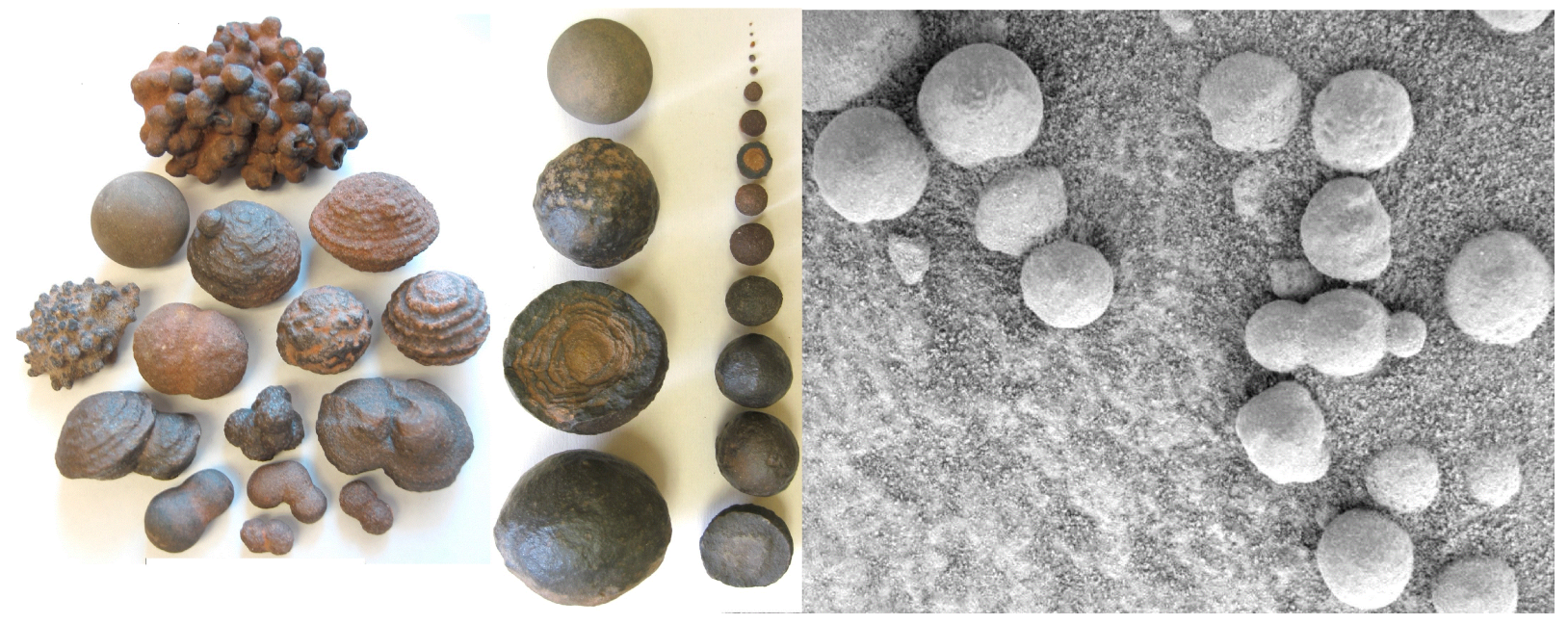

Figure 9: These spheres differ from ooids.

Figure 9 shows spheres that are different from ooids. Original description: "The Utah concretions shown on the left range in diameter from one twenty-fifth of an inch to 2 inches $(1 \mathrm{~mm}$ to $50 \mathrm{~mm}$ ), while the Martian versions on the right all measure less than one-fifth of an inch $(5 \mathrm{~mm})$ in diameter. (Scale of photos is different)." (Quoted from http://www.innovations-report.com/html/reports/earth-sciences/ report-30313.html)

Image Source: http://www.bev.ba/MOMARAFO/ET/krater/blueberries/ usa_stone_balls1.html

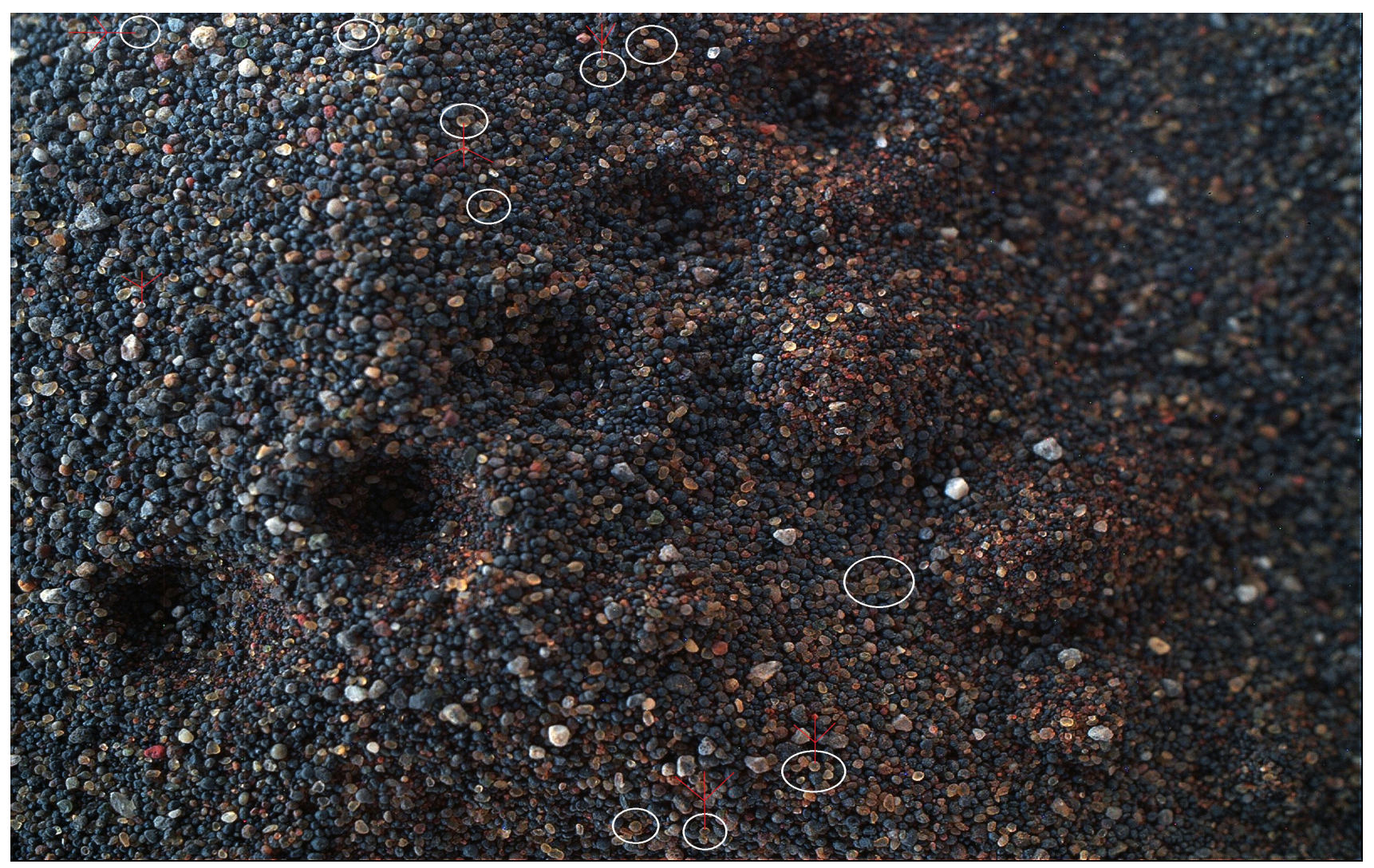

Figure 10: Eroded Martian ooids expose characteristic interior. 
Page 10 of 11

The above is a microscopic image taken at Namib Dune in Bagnold dune field, Gale Crater, Mars. In the white circles are ooids that have been eroded into hemispheres. Red arrows point to nucleus of ooids. The ooid at top left exposes its concentric layers and nucleus (Figure 10). The hemispheres are all smaller than $1 \mathrm{~mm}$ across. Image width: $2.6 \mathrm{~cm}$. For comparison with Earthly ooids that have been eroded into hemispheres, see Figure 8 above. Above image is enlarged from https:// www.flickr.com/photos/lunexit/24626790060/in/dateposted/

Image Credit: NASA/JPL-Caltech/MSSS/2di7 and titanio44 NASA's original raw image: http://mars.nasa.gov/msl/multimedia/raw/? rawid=1242MH0005620020403663C00_DXXX\&s=1242

\section{Discussion}

Living microorganisms in the soil of Mars were first reported in 1976 by Levin and Straat [2]. The report is in Science Magazine (http:// science.sciencemag.org/content/194/4271/1322) and many other scientific papers (see http://www.gillevin.com/mars.htm). This article discusses putative ooids discovered on Mars and their possible formation by microorganisms in the following paragraphs.

\section{Are they ooids?}

A1. Putative Martian ooids match ooids of Earth. An ooid consists of a nucleus (a fragment of shell, a grain of sand, or whatever) around which layers of minerals are deposited to form roughly spherical grains. A website named Sandatlas has the following webpage for 20 types of sand on Earth: http://www.sandatlas.org/sand-types/. Of the 20 types of sand on Earth, only ooid sand matches the material described in Figures 2-5, because those Martian ooids are unique for their combination of spherical shape, similar size of approximately $0.5 \mathrm{~mm}$ in diameter (see A3), and various colors that include white, yellow translucent, green, grey, and yellow. These features can be seen by comparing Figures 2-5 with the 20 types of sand on Earth. The combination of these features is also seen in nearly every Focus Merge Data Product at http://mars.nasa.gov/msl/multimedia/raw/? $s=1231 \&$ camera $=$ MAHLI and http://mars.nasa.gov/msl/multimedia/raw/? $s=1228 \&$ camera $=$ MAHLI

Such shape, size, color and concentration are characteristic of ooid sand.

A2. Martian ooid sand is seen not only at High Dune (Figure 2), but also at Namib Dune (Figures 3-5). Both High Dune and Namib Dune are portions of Bagnold dune field. The environment there over 3 billion years ago was a freshwater lake (see http:// authors.library.caltech.edu/60940/) near the Martian equator. Such distribution and environment fit those of ooid sand on Earth. Regarding geological context, ooids can be transported by water or wind or humans, as they are small. In this case, Martian wind had blown the above-mentioned ooids away from the site where they were originally formed (see http://mars.jpl.nasa.gov/msl/multimedia/images/? ImageID=7658). Anyway, geologists do not need geological context in order to correctly identify ooids (Figure 8).

A3. Ooid spheres differ from other kinds of spheres in sizes, colors and internal structures. Ooids of Earth are mostly $0.25 \mathrm{~mm}$ to $1 \mathrm{~mm}$ in diameter (Note 1). Martian ooids at Bagnold Dune are mostly about $0.5 \mathrm{~mm}$ in diameter as reported in http://www.planetary.org/multimedia/ space-images/mars/well-sorted-martian-sand.html

However, "On Mars, most of the hematite rocks ("blueberries") are about 0.16 inches ( 4 millimeters) in diameter, and no larger than 0.24 inches $(6.2 \mathrm{~mm})$. By contrast, Earth spherules exhibit a large range of sizes, not limited to only a quarter of an inch." (Quoted from the ninth paragraph in

\section{http://news.nationalgeographic.com/news/2014/02/140224-mars- blueberries-water-meteorite-space-science/)}

The colors of Martian ooids include white, yellow translucent, green, grey, and yellow as shown in figures above. Other kinds of spheres do not show all of these colors.

Regarding internal structures, ooids contain nucleus and concentric layers (Figure 10), which are rarely, if ever, seen in other kinds of spheres. In view of the above, yes, they are ooids.

Note 1: See the third paragraph in https://en.wikibooks.org/wiki/ Historical_Geology/Ooids_and_oolite and the first paragraph in http:// www.sandatlas.org/ooid-sand/)

\section{Were the Martian ooids formed by microbes?}

Regarding the formation of ooids, there are non-biological hypotheses, in which ooids get their spherical shape owing to highly agitated water [3], such as sea waves pounding on the beaches, that rolls the ooids into spherical shape. However, there is no highly agitated water in lakes. The spherical Martian ooids at Bagnold Dune are unlikely to have been formed by the non-biological mechanisms, because the Martian ooids are in a former lake with no trace of a river at the discovery sites. On the other hand, there are ample evidences for biological formation of ooids. Some of the evidences are listed in B1, $\mathrm{B} 2$ and [4-15]. In view of the above and the microbial borings in Martian ooids (Figure 7), yes, the Martian ooids should have been formed by microbes.

B1. Microbes of Earth form ooids in freshwater lake. Evidence: "Here, we show that photosynthetic microbes not only enhance early carbonate precipitation around the ooid nucleus but also control the formation of the entire cortex in freshwater ooids from Lake Geneva, Switzerland." (Quoted from the abstract of Pacton et al.: "Going nano: A new step toward understanding the processes governing freshwater ooid formation", displayed at http://geology.gsapubs.org/content/ 40/6/547.abstract)

The water in Gale Crater of Mars was once fresh water in a lake as mentioned in A2 above.

B2. Recent research confirms that microbes of Earth form ooids in seawater, as reported in the abstract of O'Reilly et al.: http:// www.hou.usra.edu/meetings/abscicon2015/pdf/7317.pdf

More evidences for microbes forming ooids are listed in different papers [6-15].

\section{Martian microbes bored holes in ooids, too}

Microbes of Earth often bore holes in ooids [1]. Microbes of Mars did the same thing in Figure 7 above.

Note 1: "The ooids have the same pattern of microboring alteration across the region. The surface and outer cortex of the ooids are punctuated with unfilled microborings, whereas the inner cortex contains two morphologies of aragonite cement filling the microborings" [1]. 
Page 11 of 11

Note 2: "Examination of such micritic ooids by scanning electron microscopy often shows evidence of microbial borings later filled by fine cement." (Quoted from Wikipedia article on ooids)

Note 3: Example of Earthly microbes boring holes in ooids can be seen at the center of the following photo: https:/en.wikipedia.org/wiki/ Ooid\#/media/File:OoidSurface01.jpg

\section{Can the Martian ooids be contaminants?}

There is no meteorite near the sites where the Martian ooids are found (Figure 6). The ooids are individual isolated particles, not articulated to any rock or meteorite. Plentiful is the amount of Martian ooids, eroded ones included (Figure 10). Martian ooids account for considerable portions of particles in the above figures. So, the Martian ooids should be indigenous, not contaminants from meteorites or other planets.

\section{Are chemistry and mineralogy necessary to identify ooids?}

Geologists usually identify ooids by visual observation without any instrument (Figure 8). Instruments can analyze chemical elements, molecules, and mineral type of sands. Results from chemical or mineralogical analyses are helpful but not necessary for identifying ooids when morphological evidence is clear (see figures above). Moreover, even if calcium carbonate $\left(\mathrm{CaCO}_{3}\right)$ is found, it may have nothing to do with life. Even if minerals of aragonite and calcite are found, they may have nothing to do with life, either, when sample size is not large enough. So, chemical or mineralogical results themselves may not be definitive for identifying ooids. Even if test results include the chemistry and mineralogy of ooids, the test results may not be interpreted as belonging to ooids (see Figure 1 in http://aem.asm.org/ content/68/8/3663/F1.expansion.html). As ooids are complex in many ways, visual judgment by experienced people is necessary in identifying ooids.

\section{Conclusion}

NASA's Mars Rover Curiosity discovered plentiful indigenous spherical ooids at High Dune and Namib Dune in Bagnold dune field, Gale Crater, Mars. Closely resembling ooids of Earth, the Martian ooids are spherical in shape, similar in size, mostly about $0.5 \mathrm{~mm}$ in diameter. Colors of the Martian ooids are various, including white, yellow translucent, green, grey, and yellow. The Martian ooids should have been formed by microbes, because ooids of Earth have recently been found to be formed by microbes and microbial borings are found in ooids of Earth and Mars. The Martian ooids are unlikely to have been formed by non-biological mechanisms, because there was no highly agitated water at the discovery sites.

\section{References}

1. Duguid SMA, Kyser TK, James NP, Rankey EC (2010) Microbes and Ooids. Journal of Sedimentary Research 80: 236-251.

2. Levin GV, Straat PA (1976) Viking Labeled Release Biology Experiment: Interim Results. Science 194: 1322-1329.

3. Tang D, Shi X, Shi Q, Wu J, Song G, et al. (2015) Organomineralization in Mesoproterozoic giant ooids. Journal of Asian Earth Sciences 107: 195-211.

4. Pacton M, Ariztegui D, Wacey D, Kilburn MR, Rollion-Bard C, et al. (2012) Going nano: a new step toward understanding the processes governing freshwater ooid formation. Geology 40: 547-550.

5. O'Reilly SS, Klepac-Ceraj V, Winter AR, Bosak T, McDermott F, et al. (2015) Molecular evidence for a microbial role in modern ooid formation and implications for their occurrence and meaning in the geological record. Astrobiology Science Conference.

6. Plee K, Ariztegui D, Martini R, Davaud E (2008) Unravelling the microbial role in ooid formation - results of an in situ experiment in modern freshwater Lake Geneva in Switzerland. Geobiology 6: 341-350.

7. Summons RE, Bird LR, Gillespie AL, Pruss SB, Roberts M, et al. (2013) Lipid biomarkers in ooids from different locations and ages: Evidence for a common bacterial flora. Geobiology 11: 420-436.

8. Miller CR, James NP (2012) Autogenic Microbial Genesis of Middle Miocene Palustrine Ooids; Nullarbor Plain, Australia. Journal of Sedimentary Research 82: 633-647.

9. Rehm UB, Rumbein WEK (2004) Laboratory cultures of calcifying biomicrospheres generate ooids - A contribution to the origin of oolites. Carnets de Géologie 3: 1-6.

10. Woods AD (2013) Microbial ooids and cortoids from the Lower Triassic (Spathian) Virgin Limestone, Nevada, USA: Evidence for an Early Triassic microbial bloom in shallow depositional environments. Global and Planetary Change 105: 91-101.

11. Xiong D, Zhiqiang S, Xin J, Hong F, Guofeng J, et al. (2015) Microbial cause for giant ooids: Evidence from the Lower Cambrian in Shizhu area, Chongqing. Journal of Palaeogeography 17: 241-248.

12. Kahle CFJ (2007) Proposed origin of aragonite Bahaman and some Pleistocene marine ooids involving bacteria, nannobacteria(?), and biofilms. Carbonates and Evaporites 22: 10-22.

13. Folk RL, Lynch FL (2001) Organic matter, putative nannobacteria and the formation of ooids and hard grounds. Sedimentology 48: 215-229.

14. Thompson JB, Huber JA (1997) Microbe and ooid associations; a possible microbial role in the origin of ooids. Abstracts with Programs Geological Society of America 29: 130.

15. Diaz MR, Swart PK, Eberli GP, Oehlert AM, Devlin Q, et al. (2015) Geochemical evidence of microbial activity within ooids. Sedimentology 62: 2090-2112. 